\title{
Risk Factors and Expected Clinical Outcomes in Kidney Transplantation Based on 1 Year Serum Creatinine Levels
}

\author{
Maroun M. Abou-Jaoude ${ }^{1,2, *}$, Ghattas Labaky ${ }^{1}$, Christelle Antar ${ }^{1}$, Walid Abou-Jaoude ${ }^{1,2}$ \\ ${ }^{1}$ Transplant Unit, The Middle East Institute of Health, Bsalim, Lebanon. \\ ${ }^{2}$ Balamand University, Lebanon \\ *Corresponding author: marounaboujaoude@hotmail.com
}

\begin{abstract}
Background: This retrospective study delineates the variable risk factors associated with differences in renal function at 1 year post kidney transplantation. Materials and Methods: Two hundred and eighty four kidney transplant patients were reviewed and divided into 4 groups according to serum creatinine levels 1 year post kidney transplantation: serum creatinine levels $<1 \mathrm{mg} / \mathrm{dl}$ (Group I; 65 patients), serum creatinine between 1 and $1.51 \mathrm{mg} / \mathrm{dl}$ (Group II; 173 patients), serum creatinine between 1.51 and $2 \mathrm{mg} / \mathrm{dl}$ (Group III; 37 patients) and serum creatinine > $2 \mathrm{mg} / \mathrm{dl}$ (Group IV; 9 patients). Baseline demographics and variable risk factors in both donors and recipients were analyzed. Results: Baseline demographics of all groups were similar, including: recipient age, cause of the original kidney disease, dialysis duration, HLA matching, induction therapy, rate of acute rejection as well as the pre and 1 year post transplant diabetes, hypertension and lipid profile. However, there were significant differences between the groups according to: donor age, donor and recipient gender, maintenance immunosuppression therapy, recipient sensitization and the severity of acute rejection episodes. The rate and type of In Hospital infections, the duration of hospital stay, the occurrence of delayed graft function, the rate and type of surgical complications at 1 year as well as the serum creatinine levels upon discharge and at 1,3 and 6 months were significantly different between the 4 groups. Conclusion: Serum creatinine level post-transplantation is a powerful predictor of long term graft survival. Although some risk factors associated with graft survival are fixed, others can be optimized.
\end{abstract}

Keywords: kidney, transplantation, risk factors, graft survival

Cite This Article: Maroun M. Abou-Jaoude, Ghattas Labaky, Christelle Antar, Walid Abou-Jaoude, andWalid Abou-Jaoude, "Risk Factors and Expected Clinical Outcomes in Kidney Transplantation Based on 1 Year Serum Creatinine Levels." American Journal of Medical Sciences and Medicine, vol. 5, no. 1 (2017): 1-9. doi: 10.12691/ajmsm-5-1-1.

\section{Introduction}

Kidney transplantation (KT) has become the treatment of choice for patients with end stage renal disease (ESRD). Not only does it improve the quality of life, but successful KT increases patients survival [1]. With better patient selection, technical improvements, more potent immunosuppression and excellent post operative care, patient and graft survival have reached interesting rates [2]. However, renal allograft dysfunction is still a common and complex problem. Appropriate management is critical for the long-term graft function and graft survival as large numbers of patients waiting for KT are suffering from failing graft and are candidates for retransplantation. This phenomena has aggravated organ shortage making the waiting list for KT longer and cumbersome on the system and society [3]. Evaluation of the graft stability is done by the transplant community by monitoring the kidney graft function in the aim to lessen adverse outcomes; serum creatinine at one year after KT has been found to be a good predictor of long-term renal graft survival [4].

Many risk factors have been identified such as: transplant center experience, immunosuppressive drug regimen, donor-to-recipient relationship, donor age and cause of brain death, recipient age and gender and dialysis time influencing the 1-year graft survival [5]. More research is needed in order to find more risk factors than those mentioned above.

The purpose of this study was to identify the variable risk factors associated with differences in renal function as measured by serum creatinine levels at 1 year after KT.

\section{Subjects and Methods}

Patients and Donors. The medical files of 284 adult patients (206 males and 78 females; mean age $41.1 \pm 13.4$ years; range 18 to 75 years) operated for KT between May 1997 and March 2015 were reviewed. All patients were Caucasians. Of these, 265 were first transplants, and the 
others having a second renal transplant (RT). Fourteen patients received kidney grafts from brain deceased donors and the remaining 270 patients from living donors after getting the approval from the local and later on national ethics committee in accordance with the Lebanese rules and regulations. The donors were 177 males and 107 females with a mean age of $35.8 \pm 10.7$ years (range from 18 to 64 years). Two hundred twenty nine patients received a kidney from identical blood group donors and the remaining 55 from compatible blood group donors.

Donor-recipient human leucocyte antigens (HLA) $\mathrm{AB} / \mathrm{DR}$ matching is shown in Figure 1. Sensitized patients were defined as those who had more than 4 pregnancies $(n=18)$, received more than 4 blood transfusions $(n=14)$, those having a retransplant $(n=17)$, and those who had a panel-reactive antibody score (anti-HLA class 1 and 2 antibodies) more than $20 \%(n=14)$. Four patients had both multiple pregnancies and blood transfusions and 2 patients had a retransplant with multiple transfusions. While chronic glomerulonephritis and focal segmental glomerulosclerosis were the most common causes, the etiology of renal disease was unclear in 97 patients (Table 1). The pre-transplant dialysis duration ranged from 0 to 132 months (mean $16.5 \pm 23.0$ months). Fourty four patients had a preemptive KT.

Table 1. Causes of End Stage Renal Disease

\begin{tabular}{|c|c|c|c|c|c|}
\hline Cause & $\begin{array}{l}\text { All patients } \\
(\mathrm{n}=284)\end{array}$ & $\begin{array}{l}\text { Group I } \\
(n=65)\end{array}$ & $\begin{array}{l}\text { Group II } \\
(\mathrm{n}=173)\end{array}$ & $\begin{array}{c}\text { Group III } \\
(\mathrm{n}=37)\end{array}$ & $\begin{array}{c}\text { Group IV } \\
(n=9)\end{array}$ \\
\hline Unknown & 97 & 19 & 63 & 12 & 3 \\
\hline Chronic pyelonephritis & 23 & 5 & 14 & 4 & 0 \\
\hline Chronic glomerulonephritis & 31 & 7 & 17 & 5 & 2 \\
\hline Polycystic kidney disease & 22 & 6 & 12 & 3 & 1 \\
\hline Diabetic nephropathy & 14 & 4 & 9 & 0 & 1 \\
\hline Nephroangiosclerosis & 17 & 5 & 10 & 1 & 1 \\
\hline Berger disease & 12 & 4 & 6 & 2 & 0 \\
\hline Alport disease & 5 & 2 & 3 & 0 & 0 \\
\hline Interstitial nephritis & 9 & 2 & 5 & 2 & 0 \\
\hline Amyloidosis & 3 & 2 & 1 & 0 & 0 \\
\hline Retransplant & 19 & 2 & 15 & 1 & 1 \\
\hline FSGS & 24 & 3 & 14 & 7 & 0 \\
\hline Renal hypoplasia & 3 & 1 & 2 & 0 & 0 \\
\hline Lupus nephritis & 4 & 3 & 1 & 0 & 0 \\
\hline Nephronophtyse & 1 & 0 & 1 & 0 & 0 \\
\hline
\end{tabular}

$\mathrm{P}=$ N.S.

Abbreviation: FSGS, focal segmental glomerulosclerosis.

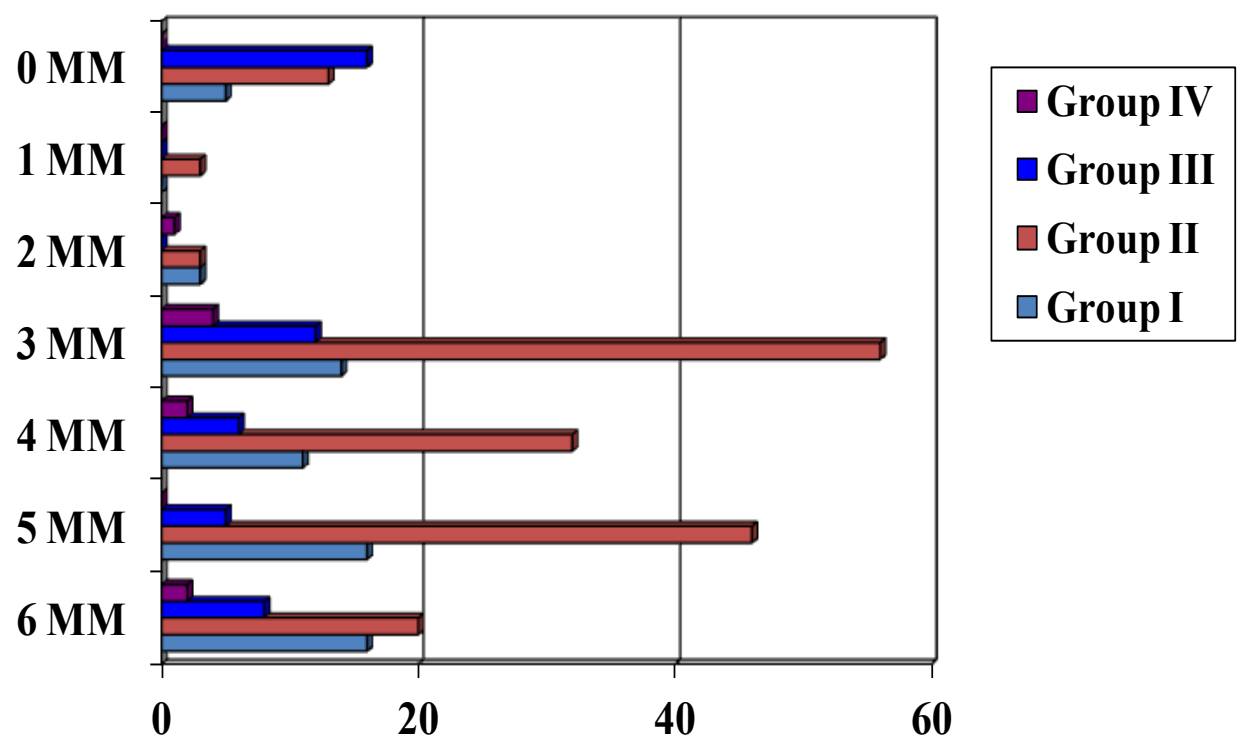

Group I (Serum Creatinine $<1 \mathrm{mg} / \mathrm{dl})$; Group II $(1 \mathrm{mg} / \mathrm{dl}<$ Serum Creatinine $<1.5 \mathrm{mg} / \mathrm{dl})$; Group III $(1.51 \mathrm{mg} / \mathrm{dl}<$ Serum Creatinine $<2 \mathrm{mg} / \mathrm{dl})$; Group IV (Serum Creatinine $>2 \mathrm{mg} / \mathrm{dl}$ ) $P$ value $=$ N.S

Figure 1. The HLA AB-DR matching between donors and recipients (MM = Mismatching) 
Operation. All transplants were heterotopic inserted in the iliac fossa. Vascular anastomoses were done with the recipient external iliac vessels in an end-to-side manner, the vein first then the artery using prolene 5-0 for the vein and 6-0 for the artery. Vesico-ureteral anastomosis was done as described by Shanfiel [6]. To minimize urological complications, an internal double-J ureteric stent was inserted before finishing the uretero-neocystostomy, then removed 6 weeks after KT by cystoscopy [7]. A closed drain was left in the operative area before wound closure, and removed when the drainage is $<50 \mathrm{ml} /$ day. Foley catheters were removed on day 4 post KT and urine cultures were routinely obtained.

Perioperative Antibiotic Prophylaxis. Intra-operative antibiotic prophylaxis with intravenous first-generation cephalosporins (or others in case of specific preoperative infections or drug allergies) was instituted for all patients $1 \mathrm{hr}$ before the surgery, and continued for 3 doses thereafter. Intravenous ganciclovir was administered during hospitalization, and the dose adjusted according to the renal graft function (glomerular filtration rate). Oral anti-cytomegalovirus (CMV) prophylaxis (valacyclovir in 103 patients and valganciclovir in 87 patients) was then administered for 3 months after hospital discharge, or for 6-month period in CMV high-risk patients (the use of anti-thymocyte globulin-Fresenius (ATG-F) extended protocol, multiple acute rejection (AR) episodes needing high dose of steroids, or CMV-negative recipient receiving a kidney from a CMV-positive donor). In addition, trimethoprine/sulfametoxazole was prescribed for 1 year after the transplant for Pneumocystis carinii prophylaxis.

Immunosuppressive Regimen. Induction therapy was given to 196 patients: 89 patients received a single intraoperative ATG-F bolus $(6 \mathrm{mg} / \mathrm{kg})$ and 76 patients received anti-interleukin 2 receptor (anti-IL2 R) antibodies. Among the 69 highly sensitized patients, 31 received the extended protocol of ATG-F ( $6 \mathrm{mg} / \mathrm{kg}$ during the surgery followed by $4 \mathrm{mg} / \mathrm{kg}$ every other day for 3 doses). The remaining 38 highly sensitized patients did not receive the complete course of ATG-F extended protocol for either medical (the occurrence of adverse effects related to the drug) or logistic reasons. In 88 patients, no induction therapy was used. Maintenance immunosuppression consisted of intravenous methylprednisolone (500 mg), given during surgery than tapered progressively over the next four weeks to $0.2 \mathrm{mg} / \mathrm{kg} /$ day of prednisone (Pred). Cyclosporine microemulsion (CyA-me) was given after the transplant (5 $\mathrm{mg} / \mathrm{kg}$ bid), or was delayed in case of slow graft function (SGF) or delayed graft function (DGF); the dose adjusted to a C2 levels of $1700 \mathrm{ng} / \mathrm{ml}$ (using the monoclonal radioimmunoassay on whole blood) during the first month. Tacrolimus (Tacro) was administered at a dose of 0.1 $\mathrm{mg} / \mathrm{kg}$ bid, and monitored for a trough level of 12-15 $\mathrm{ng} / \mathrm{ml}$ during the first month. Mycophenolate mofetil (MMF) was started 48 hours before KT at 1 gm twice a day (in CyA-me patients) or $500 \mathrm{mg}$ tid (in Tacro patients).

Diagnosis of infections. Urine, throat, nose, peritoneal fluid (in peritoneal dialysis patients) and blood (in case of hemodialysis catheter) cultures were obtained before KT. They were all negative. Serology for CMV, herpes simplex virus (HSV), Varicella, Epstein barr virus (EBV) and Toxoplasmosis virus were obtained before transplantation. Active infections excluded KT. After KT, blood, urine and sputum cultures for bacteria and fungi were done when indicated. The indwelling arterial and central venous monitoring catheters were removed in all patients as soon as possible and their tips were cultured. Similarly, intravascular catheters used for hemodialysis access were also cultured. Cultures were also taken from other sites (e.g. drains, peritoneal catheters) when patients had persistently elevated leucocytes counts or episodes of fever. Intravascular catheters were considered infected, using the semi-quantitative culture method of Maki technique [8], if more than 15 organisms were cultured from the tip of the removed catheters regardless if fever was present or whether blood cultures were positive. The urine was considered infected if greater than 100.000 organisms $/ \mathrm{ml}$ were present. Viral infections were diagnosed on the basis of polymerase chain reaction (PCR) in blood, urine or tissue specimen, or histological proof of tissue invasion. CMV testing was performed only in symptomatic patients (CMV disease or suspicion of CMV syndrome). Detection of BK virus also was requested in case of occurrence of symptoms, or a rise in serum creatinine. In this case, kidney graft biopsy and urine or blood BK-PCR tests were performed. Specific immunohistochemistry coloration was done systematically in all kidney graft biopsies. Bronchoscopy and bronchial lavage were performed when a pulmonary infiltrate was present and sputum samples were inadequate. Chest X-rays were taken daily until extubation, then when indicated.

All episodes of infections during the first year after KT, whether symptomatic or asymptomatic, were analyzed. These infections were divided into 2 groups: In hospital infections and outpatient infections.

Diagnosis of rejection. Kidney biopsies were performed when abnormal renal graft function tests occurred, after ruling out surgical complications by appropriate radiological investigations. The histological criteria for AR proposed by the Banff classification were used [9]. AR episodes were treated with a 3-day course of bolus steroids. Steroid-resistant rejections were treated with an additional course of ATG-F.

Statistical Analysis. The data were analyzed using SPSS software for Windows (Statistical Product and Service Solutions, version 13.0, SSPS Inc., Chicago, IL, USA). Data are reported as the mean \pm SD or percentage of the total. Intergroup significance was determined by Student t-test (continuous variables) and the Fisher's exact test (categorical variables). Statistical significance set at $\mathrm{P}<0.05$.

\section{Results}

The patients were divided into 4 groups based on serum creatinine level at 1 year after KT. Group I (serum creatinine $<1 \mathrm{mg} / \mathrm{dl}$; $\mathrm{n}=65$ patients), Group II $(1 \mathrm{mg} / \mathrm{dl}<$ serum creatinnine $<1.5 \mathrm{mg} / \mathrm{dl} ; \mathrm{n}=173$ patients), Group III ( $1.51 \mathrm{mg} / \mathrm{dl}<$ serum creatinine $<2 \mathrm{mg} / \mathrm{dl} ; \mathrm{n}=37$ patients) and Group IV (serum creatinine $>2 \mathrm{mg} / \mathrm{dl} ; \mathrm{n}=9$ patients). Pre-transplant factors related to the patients and donors demographics are described in Table 2. Donors were older in Group IV and III (mean age: $45.4+/-11.4$ and 40.0 +/10.9 respectively) as compared to Group II (mean age: $35.7+/-10.4)$ and Group I (mean age $32.3+/-9.9)(\mathrm{P}<$ 
0.05) There were more females recipients in Group I and more female donors in Group IV and this was statistically significant. More immunologically sensitized patients were found in Group I ( $\mathrm{n}=27$ patients; $41.3 \%$ ) compared to Group IV ( $\mathrm{n}=3$ patients, 33.3\%), Group III $(\mathrm{n}=7$ patients, $18.9 \%)$ and Group II $(\mathrm{n}=32$ patients, $18.3 \%)(\mathrm{P}=$ $0.002)$. Induction and maintenance immunosuppression protocols are described in Figure 2 and Table 3.

Table 2. Patients and Donors Demographics

\begin{tabular}{|l|c|c|c|c|c|}
\hline & $\begin{array}{c}\text { Group I } \\
(\mathrm{n}=65)\end{array}$ & $\begin{array}{c}\text { Group II } \\
(\mathrm{n}=173)\end{array}$ & $\begin{array}{c}\text { Group III } \\
(\mathrm{n}=37)\end{array}$ & $\begin{array}{c}\text { Group IV } \\
(\mathrm{n}=9)\end{array}$ & P value \\
\hline Recipient age (years) & $42.3+/-13.7$ & $40.1+/-13.6$ & $42.6+/-12.9$ & $44.6+/-10.6$ & N.S. \\
\hline Recipient gender (M/F) & $25 / 40$ & $139 / 34$ & $33 / 4$ & $9 / 0$ & 0.000 \\
\hline Donor age (years) & $32.3+/-9.9$ & $35.7+/-10.4$ & $40.0+/-10.9$ & $45.4+/-11.4$ & 0.000 \\
\hline Donor gender (M/F) & $51 / 14$ & $103 / 68$ & $19 / 18$ & $2 / 7$ & $<0.001$ \\
\hline $\begin{array}{l}\text { D/R blood group } \\
\text { Identical }\end{array}$ & 53 & 138 & 30 & & 8 \\
Compatible & 12 & 35 & 7 & 1 & N.S. \\
\hline $\begin{array}{l}\text { Pre-transplant dialysis } \\
\text { Duration (month) }\end{array}$ & $22.3+/-29.0$ & $14.2+/-18.9$ & $17.5+/-28.7$ & $14.6+/-10.8$ & N.S. \\
\hline $\begin{array}{l}\text { Preemptive transplantation } \\
\text { (patients) }\end{array}$ & 4 & 30 & 9 & & 1 \\
\hline
\end{tabular}

Table 3. Maintenance Immunosuppression

\begin{tabular}{|l|c|c|c|c|}
\hline & $\begin{array}{c}\text { Group I } \\
(\mathrm{n}=65)\end{array}$ & $\begin{array}{c}\text { Group II } \\
(\mathrm{n}=173)\end{array}$ & $\begin{array}{c}\text { Group III } \\
(\mathrm{n}=37)\end{array}$ & $\begin{array}{c}\text { Group IV } \\
(\mathrm{n}=9)\end{array}$ \\
\hline NAP & 1 & 7 & 5 & 1 \\
\hline NCP & 9 & 64 & 0 & 4 \\
\hline FAP & 1 & 0 & 18 & 0 \\
\hline FCP & 47 & 78 & 5 & 2 \\
\hline N/FCP & 4 & 13 & 2 & 0 \\
\hline N/RCP & 0 & 4 & 0 & 0 \\
\hline FRCP & 1 & 1 & 0 & 0 \\
\hline F/NRCP & 0 & 1 & 1 & 1 \\
\hline F/NCP & 1 & 4 & 3 & 0 \\
\hline Others & 1 & 1 & & 0 \\
\hline
\end{tabular}

$\mathrm{P}=\mathrm{N} . \mathrm{S}$.

Abbreviation: N-Neoral, $\mathrm{F}=\mathrm{FK} 506, \mathrm{R}=$ Rapaczathioprine, $\mathrm{C}=$ Mycophenolate Mofetil, $\mathrm{P}=$ Prednisone.

\section{Induction Therapy}

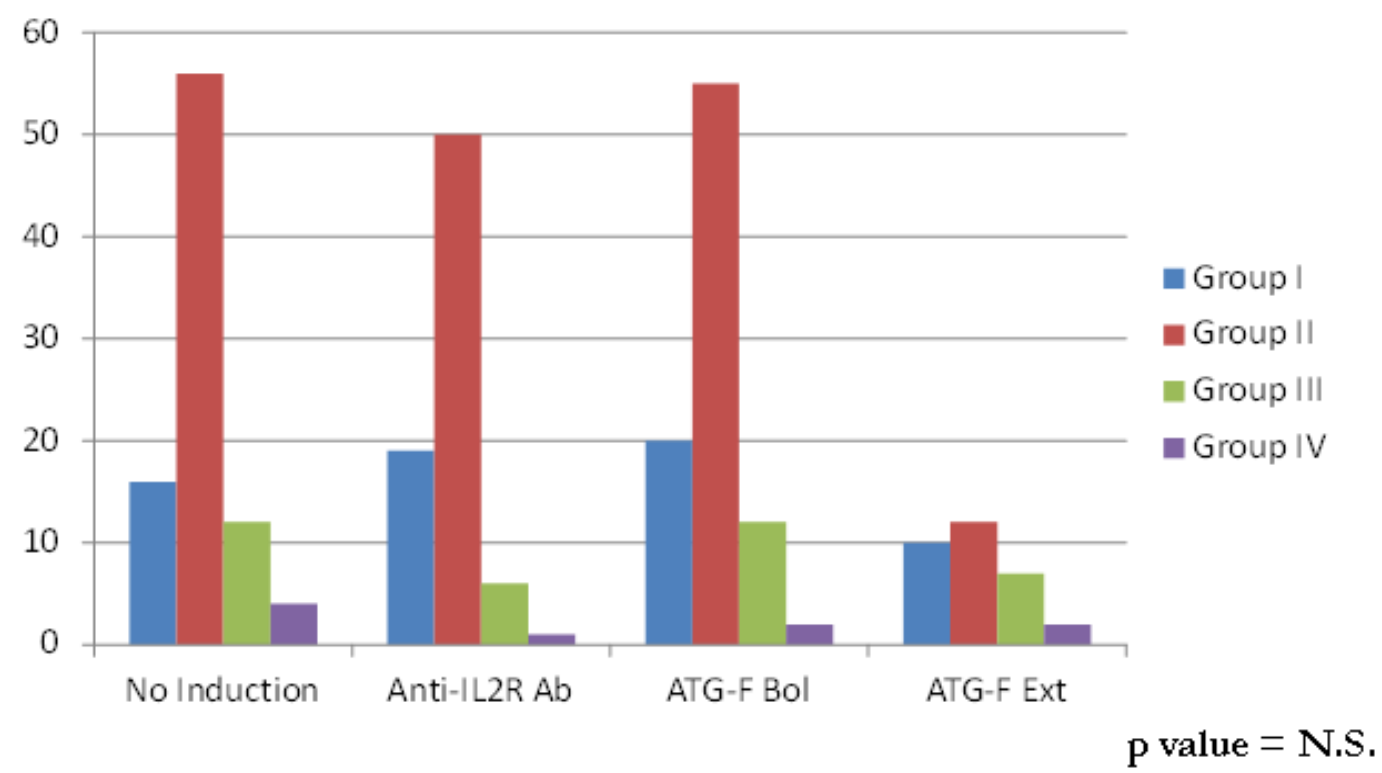

Figure 2. Induction therapy 
Table 4. Hematologic Profile

\begin{tabular}{|c|c|c|c|c|c|}
\hline & $\begin{array}{l}\begin{array}{l}\text { Group I } \\
(\mathrm{n}=65)\end{array} \\
\end{array}$ & $\begin{array}{l}\text { Group II } \\
(\mathrm{n}=173)\end{array}$ & $\begin{array}{c}\text { Group III } \\
(\mathrm{n}=37)\end{array}$ & $\begin{array}{c}\text { Group IV } \\
(\mathrm{n}=9)\end{array}$ & $P$ value \\
\hline $\begin{array}{c}\text { Pre-Tx Hb } \\
\text { Blood level }^{1}\end{array}$ & $10.2+/-2.4$ & $10.2+/-2.0$ & $10.6+/-2.0$ & $9.8+/-2.1$ & N.S. \\
\hline $\begin{array}{l}\text { Post-Tx Hb } \\
\text { Blood level }^{1} \\
\end{array}$ & $7.0+/-1.6$ & $7.5+/-1.8$ & $7.2+/-1.5$ & $7.1+/-1.8$ & N.S. \\
\hline $\mathrm{Hb}$ difference ${ }^{1}$ & $3.2+/-2.1$ & $2.8+/-1.7$ & $3.5+/-2.1$ & $2.8+/-2.0$ & N.S. \\
\hline $\begin{array}{l}\text { Pre-Tx Plat } \\
\text { Blood level }^{2}\end{array}$ & $222384+/-91580$ & $227710+/-80833$ & $211467+/-49604$ & $231333+/-69996$ & N.S. \\
\hline $\begin{array}{l}\text { Post-Tx Plat } \\
\text { Blood level }^{2}\end{array}$ & $121538+/-56711$ & $141768+/-63069$ & $110189+/-49645$ & $153666+/-79068$ & $=0.007$ \\
\hline Plat difference ${ }^{2}$ & $104476+/-83876$ & $87763+/-65889$ & $103548+/-58110$ & $87777+/-67870$ & N.S. \\
\hline
\end{tabular}

$1=\mathrm{gm} / \mathrm{dl}$

$2=/ \mathrm{mm}^{3}$

Abbreviation: $\mathrm{Tx}=$ Transplant, $\mathrm{Hb}=$ Hemoglobin, Plat $=$ Platelets

Table 5. Metabolic Profile

\begin{tabular}{|c|c|c|c|c|}
\hline & $\begin{array}{c}\text { Group I } \\
(\mathrm{n}=65)\end{array}$ & $\begin{array}{c}\text { Group II } \\
(\mathrm{n}=173)\end{array}$ & $\begin{array}{c}\text { Group III } \\
(\mathrm{n}=37)\end{array}$ & $\begin{array}{c}\text { Group IV } \\
(\mathrm{n}=9)\end{array}$ \\
\hline Pre-Tx FBS $^{1}$ & $93.2+/-24.0$ & $93.6+/-28.3$ & $90.9+/-16.0$ & $83.4+/-11.3$ \\
\hline Post-Tx FBS $^{1}$ & $97.1+/-43.4$ & $94.1+/-46.4$ & $79.6+/-42.3$ & $85.6+/-36.0$ \\
\hline Pre-Tx Diabetes & $7(10.8 \%)$ & $13(7.5 \%)$ & $0(0 \%)$ & $26(22.2 \%)$ \\
\hline Poat-Tx need for Insulin & $13(20 \%)$ & $24(13.9 \%)$ & $3(8.1 \%)$ & $1(11.1 \%)$ \\
\hline Pre-Tx BMI & $19.7+/-10.8$ & $20.7+/-10.3$ & $24.3+/-6.9$ & $22.8+/-8.9$ \\
\hline Pre-Tx HBP & $36(55.4 \%)$ & $106(61.3 \%)$ & $24(64.9 \%)$ & $5(55.6 \%)$ \\
\hline Post-Tx HBP $^{1}$ & $28(43.14 \%)$ & $91(52.6 \%)$ & $20(54.1 \%)$ & $4(44.4 \%)$ \\
\hline Pre-Tx serum Triglycerides $^{1}$ & $166.5+/-79.7$ & $189.0+/-112.8$ & $200.4+/-93.0$ & $194.2+/-73.3$ \\
\hline Pre-Tx serum Cholesterol $^{1}$ & $150.6+/-54.4$ & $165.0+/-99.0$ & $180.0+/-157.9$ & $146.6+/-84.6$ \\
\hline Post-Tx serum Cholesterol $^{1}$ & $182.5+/-49.9$ & $177.2+/-52.8$ & $194.5+/-61.6$ & $185.5+/-45.3$ \\
\hline Post-Tx serum HDL $^{1}$ & $182.0+/-62.9$ & $178.0+/-74.1$ & $164.0+/-115.7$ & $170.1+/-103.6$ \\
\hline Post-Tx serum LDL $^{1}$ & $37.9+/-27.6$ & $29.6+/-25.1$ & $28.5+/-22.7$ & $22.6+/-22.0$ \\
\hline
\end{tabular}

$1=\mathrm{mg} / \mathrm{dl}$

Abbreviation: Tx $=$ Transplant, FBS $=$ Fasting blood sugar, BMI $=$ Body mass index, HBP $=$ High blood pressure, HDL $=$ High density lipoprotein, LDL - Low density lipoprotein $\mathrm{P}=$ N.S.

Hematologic and metabolic profiles. While pre and post RT hematological profiles were similar in the 4 groups, post transplant platelets blood levels were significantly different with the lowest noted in Group III (Table 4). The number of patients who needed post transplant blood transfusions was also similar between the 4 groups (18, 31 , 12 and 3 patients respectively in Group I, II, III and IV). None of the characteristics in the metabolic profile both pre and at 1 year post transplantation reaches significantly difference. It includes: pre transplant diabetes rate and body mass index (BMI), the need for insulin therapy during the first year after $\mathrm{KT}$, pre and 1 year post transplant fasting blood sugar levels, hypertension rate and lipid profiles (Table 5).

Acute Rejection. AR occurred in 45 patients (15.8\%) between day 2 and day 121 after KT. There were 9 patients in Group I, 29 patients in Group II, 4 patients in Group III and 3 patients in Group IV ( $p$ value $=$ N.S.). All the AR cases responded well to steroid bolus treatment. A total of 12 episodes of steroid-resistant acute rejection occurred requiring ATG-F therapy. They were statistically more frequent in Group III (75\%) and Group IV (66\%) than in Group I (22.2\%) and Group II (17.2\%) (p value $=$ 0.036).

Infections. One hundred eighteen out of 284 patients (41.5\%) developed a total of 192 infectious episodes during or up to 1 year after hospitalization. Sixty five of them $(55 \%)$ developed infections during their stay in the hospital, 34 patients $(28.8 \%)$ after their discharge and 19 patients $(16.2 \%)$ developed infections during and after hospitalization. In total, 192 infectious episodes at a rate of 1.62 infectious episode / patient were diagnosed. These included 103 infections occurring during the patient's hospital stay and 89 infections up to 1 year later. The infections consisted of 159 bacterial (82.8\%), 24 viral $(12.5 \%)$ and 9 fungal infections $(4.7 \%)$.

In Hospital infections. The rate of infected patients (55\%; 8 infections in 5 patients) was higher in Group IV in comparison to $43.2 \%$ (23 infections occurring in 16 patients) in Group III, followed by $38.4 \%$ (29 infections in 25 patients) in Group I and 21.9\% (43 infections in 38 patients) in Group II and this difference was statistically different $(p<0.02)$. Bacterial infections were more common in Group III (96\%) and Group II (93\%) and viral 
infections more frequent in Group IV (12.5\%) and Group $1(10.3 \%)$ (Table 6).

Outpatient infections. The outpatient infections (from hospital discharge till 1 year after KT) rate was similar in the 4 groups. Twenty five infections occurred in 13 patients in Group I, 48 infections in 33 patients in Group II, 13 infections in Group III and 3 infections in Group IV. Bacterial and viral infections were more frequent but statistically not significant in Group IV but fungal infections more common in Group I (Table 6).

Total infections. The rate of infected patients up to 1 year after KT was not different between the 4 groups: $49 \%$ in Group I, 35.8\% in Group II, 51.4\% in Group III and $55.6 \%$ in Group IV. When related to the number of infected patients, the number of infectious episodes was statically higher in Group IV (11 in 5 infected patients) in comparison to Group III (36 in 19 patients), Group I (54 in 32 patients) and Group II (91 in 62 patients). Bacterial infections were the lowest in Group II (81\%) and Group IV (82\%) when compared to Group III (83\%) and Group I $(85 \%)$. Viral and fungal infections were not different between the 4 groups (Table 6).

Bacterial infections. Most of the In-Hospital infections were bacterial (93 out of 103 infections; 90.4\%).Urinary tract infections were the most frequent $(51.6 \%)$ followed by intravascular catheter-related infections (19.3\%). respiratory infections $(9.6 \%)$ and external drainage catheter infections $(7.5 \%)$. E. Coli and Klebsiella were the most common organisms identified in the urinary infections, while Staphylocococcus epidermidis was most common in the catheter-related infections. Outpatient infections, there were fewer bacterial infections (66 episodes; 74.1\%) and their distribution was different except for the urinary tract infections which were similar with respect to frequency $(65.1 \%)$ and causative organisms (Table 7).

Viral infections: Five of the 24 viral infections were acquired during the patient's stay in the hospital. They were 4 oral Herpes and 1 Hepatitis $\mathrm{C}$ infections. The remaining 19 viral infections were divided into 1 oral Herpes, 1 penis papillomatosis and $17 \mathrm{CMV}$ infections (89.4\%). All the CMV infections are described in Table 8 in accordance to the donor and recipient CMV status. All these infections were diagnosed by positive CMV-PCR testing or tissue biopsy and all the patients responded well to IV ganciclovir for 2 weeks followed by oral treatment for a 3 month period.

Fungal infections: There were 9 cases of fungal infections: 5 cases occurred during the patient's hospital stay (3 oral. 1 esophageal and 1 vaginal infections) and 4 others after the patient's discharge from the hospital (2 oral, 1 esophageal and 1 ungueal). All cases were treated with oral Fluconazole.

Patients and Grafts outcome. The patient's hospital stay duration was longer in Group IV as well as the rate of DGF. In all groups, there was a steady decline in serum creatinine levels from discharge till 12 months after (Table 9). Surgical complications were statistically higher in Group III (9 patients; $24.3 \%$ ) than in group IV (1 patient; $11.1 \%$ ), Group II (13 patients; 7.5\%) and Group I (4 patients; $6.2 \%$ ). The type of these complications are described in Table 10 .

Table 6. Infections

\begin{tabular}{|c|c|c|c|c|c|}
\hline & $\begin{array}{l}\text { Group I } \\
(\mathrm{n}=65)\end{array}$ & $\begin{array}{l}\text { Group II } \\
(\mathrm{n}=173)\end{array}$ & $\begin{array}{c}\text { Group III } \\
(\mathrm{n}=37)\end{array}$ & $\begin{array}{c}\text { Group IV } \\
(\mathrm{n}=9)\end{array}$ & $P$ value \\
\hline \multicolumn{6}{|c|}{ In Hospital Infections } \\
\hline - Bacterial & $25(86 \%)$ & $40(93 \%)$ & $22(96 \%)$ & $6(756 \%)$ & $<0.02$ \\
\hline - Viral & $3(10.3 \%)$ & $1(2 \%)$ & $0(0 \%)$ & $1(12.5 \%)$ & $<0.02$ \\
\hline - Fungal & $1(3.5 \%)$ & $2(5 \%)$ & $1(5 \%)$ & $1(12.5 \%)$ & N.S. \\
\hline \multicolumn{6}{|c|}{ Out of Hospital Infections } \\
\hline - Bacterial & $21(84 \%)$ & $34(71 \%)$ & $8(61.5 \%)$ & $3(100 \%)$ & N.S. \\
\hline - Viral & $2(8 \%)$ & $12(25 \%)$ & $5(38.5 \%)$ & $0(0 \%)$ & N.S. \\
\hline - Fungal & $2(8 \%)$ & $2(4.2 \%)$ & $0(0 \%)$ & $0(0 \%)$ & N.S. \\
\hline \multicolumn{6}{|c|}{ Total Infections } \\
\hline - Bacterial & $46(85 \%)$ & $74(81 \%)$ & $30(83 \%)$ & $9(82 \%)$ & $<0.022$ \\
\hline - Viral & $5(9 \%)$ & $13(14 \%)$ & $5(14 \%)$ & $1(9 \%)$ & N.S. \\
\hline - Fungal & $3(5.5 \%)$ & $4(4.5 \%)$ & $1(3 \%)$ & $1(9 \%)$ & N.S. \\
\hline
\end{tabular}

Table 7. Distribution of Postoperative Bacterial Infections

\begin{tabular}{|l|c|c|}
\hline Site of Infection & In Hospital $(\mathrm{n}=93)$ & Out of Hospital $(\mathrm{n}=66)$ \\
\hline Urinary & $48(51.6 \%)$ & $58(65.1 \%)$ \\
\hline External drainage catheter & $7(7.5 \%)$ & $0(0 \%)$ \\
\hline Intravascular catheter & $18(19.3 \%)$ & $0(0 \%)$ \\
\hline Respiratory & $9(9.6 \%)$ & $3(0 \%)$ \\
\hline Colitis & $6(6.4 \%)$ & $1(1.5 \%) \mathrm{skin}$ \\
\hline Wound & $1(1 \%)$ & $4(28.9 \%)$ \\
\hline Others & $4(4.6 \%)$ & \\
\hline
\end{tabular}


Table 8. Post-Transplant CMV Disease and Type

\begin{tabular}{|c|c|c|c|c|}
\hline & $\begin{array}{c}\text { Group I } \\
(\mathrm{n}=65)\end{array}$ & $\begin{array}{c}\text { Group II } \\
(\mathrm{n}=173)\end{array}$ & $\begin{array}{c}\text { Group III } \\
(\mathrm{n}=37)\end{array}$ & $\begin{array}{c}\text { Group IV } \\
(\mathrm{n}=9)\end{array}$ \\
\hline CMV disease & 2 & 10 & 5 & 0 \\
\hline CMV type & GI (2) & GI (9), Ur (1) & GI (3), Resp (1), Ur (1) & 0 \\
\hline $\begin{array}{c}\text { CMV timing } \\
\text { (days) }\end{array}$ & 32,96 & $\begin{array}{c}\text { GI: } \\
\text { (28,49,76,120,120,125,126,194,310 } \\
\text { Ur: } 125\end{array}$ & $\begin{array}{c}\text { GI: } 90,92,210 \\
\text { Resp: } 70 \\
\text { Ur: } 92\end{array}$ & 0 \\
\hline D/R status & P/P (2) & P/N (4), P/P (6) & $\begin{array}{c}\text { P/N (2) } \\
\text { P/P (3) }\end{array}$ & 0 \\
\hline \multirow{2}{*}{$\begin{array}{c}\text { Induction therapy } \\
\text { None (1) }\end{array}$} & ATG-F Ext (1) & $\begin{array}{c}\text { None (1) } \\
\text { ATG-F Bol (3) }\end{array}$ & $\begin{array}{c}\text { ATG-F Bol (2) } \\
\text { ATG-F Ext (2) } \\
\text { Anti-IL2R Ab (1) }\end{array}$ & 0 \\
\hline
\end{tabular}

$\mathrm{P}=\mathrm{N} . \mathrm{S}$.

Abbreviation: $\mathrm{D}=$ Donor, $\mathrm{R}=$ Recipient, $\mathrm{N}=$ Anti-CMV IgG negative, $\mathrm{P}=$ Anti-CMV IgG positive, $\mathrm{GI}=$ Gastro-intestinal, Ur $=\mathrm{Urinary}, \mathrm{Resp}=$ Respiratory, ATG-F Ext $=$ Anti-Thymocyte Globulin Fresenius Extended protocol, ATG-F Bol = Anti-Thymocyte Globulin Fresenius Bolus protocol, Anti-IL2R Ab $=$ Anti-Interleukine 2 receptor antibodies.

Table 9. Patient and Graft Outcome

\begin{tabular}{|c|c|c|c|c|}
\hline & $\begin{array}{c}\text { Group I } \\
(n=65)\end{array}$ & $\begin{array}{l}\text { Group II } \\
(n=173)\end{array}$ & $\begin{array}{c}\text { Group III } \\
(\mathrm{n}=37)\end{array}$ & $\begin{array}{c}\text { Group IV } \\
(\mathrm{n}=9)\end{array}$ \\
\hline \multicolumn{5}{|l|}{ Hospital stay } \\
\hline Mean +/- SD (days) & $11.0+/-3.5$ & $11.0+/-4.5$ & $13.1+/-6.1$ & $16.5+/-10.1$ \\
\hline Range (days) & $6-24$ & $6-48$ & $6-40$ & $7-41$ \\
\hline DGF & $1(1.5 \%)$ & $4(2.3 \%)$ & $3(8.1 \%)$ & $2(22.2 \%)$ \\
\hline Se Crea upon discharge ${ }^{1}$ & $1.17+/-0.62$ & $1.34+/-0.43$ & $1.98+/-0.92$ & $2.56+/-1.11$ \\
\hline SeCrea@1 month ${ }^{1}$ & $1.07+/-0.31$ & $1.34+/-0.30$ & $1.85+/-0.44$ & $2.47+/-0.97$ \\
\hline Se Crea@3 months ${ }^{1}$ & $0.97+/-0.29$ & $1.34+/-0.66$ & $1.69+/-0.30$ & $2.39+/-1.15$ \\
\hline Se Crea@6 months ${ }^{1}$ & $0.92+/-0.19$ & $1.25+/-0.24$ & $1.60+/-0.27$ & $2.09+/-1.00$ \\
\hline Se Crea@12 months ${ }^{1}$ & $0.83+/-0.11$ & $1.20+/-0.15$ & $1.68+/-0.13$ & $2.47+/-0.94$ \\
\hline
\end{tabular}

$\mathrm{P}=\mathrm{N} . \mathrm{S}$.

${ }^{1}=\mathrm{mg} / \mathrm{dl}$

Abbreviation: $\mathrm{DGF}=$ Delayed graft function, $\mathrm{Se}=$ Serum, Crea $=$ Creatinine .

Table 10. Type of Surgical Complications

\begin{tabular}{|l|c|c|c|c|}
\hline & $\begin{array}{c}\text { Group I } \\
(4 / 65)\end{array}$ & $\begin{array}{c}\text { Group II } \\
(13 / 173)\end{array}$ & $\begin{array}{c}\text { Group III } \\
(9 / 37)\end{array}$ & Group IV \\
$(1 / 9)$
\end{tabular}

$P$ value $=0.037$

\section{Discussion}

Since several years, many studies have been done to identify the factors which affect kidney allograft survival. In our study, we did identify some pre-transplant risk factors such as: donor age, donor and recipient gender and recipient sensitization. Other post-transplant risk factors were: immunosuppressive drug regimen, acute rejection severity, In Hospital rate and type of infections, length of hospital stay, DGF, bacterial infections rate at 1 year, rate and type of surgical complications at 1 year and serum creatinine level upon discharge and at 1, 3 and 6 months after KT. However, there were no effect of recipient age, cause of the original kidney disease, dialysis duration, HLA matching between donors and recipients, induction therapy administration, rate of acute rejection, as well as the pre- and 1 year post-transplant metabolic profile on 1 -year graft function.

Compared to the literature, we did not find any effect of donor-to recipient relationship, recipient age, dialysis duration, CMV status, PRA level and HLA matching between donors and recipients. The lack of effect of recipient age on 1-year graft survival is most probably due to the inclusion of older population with a cut-off age of 65 years [10] when compared to our population which included a relatively younger group. Although previous 
studies reported an association between causes of ESRD and graft survival [11], our study did not show any effect of original kidney disease, most likely related to the undetermined etiology which is explained by the late diagnosis of ESRD in Lebanon and difficulties to perform kidney biopsy which could influence the results. Some studies have shown that a period of pre-transplant dialysis longer than 24 months is associated to earlier occurrence of allograft failure [12], in comparison to recipients who had a dialysis duration of 6 months or shorter. This relation was not proved in our study where no effect of dialysis duration was identified. Data from previous studies clarify the concept that an increase in the number of HLA mismatches increases the risk of graft loss [13]. In our study HLA mismatch did not result in much difference probably due to the fact that the studied population had the same racial and ethnic backgrounds.

Acute rejection within the first year after transplantation had a detrimental effect on long-term graft survival, and changes in induction protocol also affected graft survival [14]. Such results were not reproducible in our study probably due to the small number of patients in group IV. In our study, we did not find any negative effect of pre-transplant diabetes or hypertension on graft function and survival in contradiction to many studies in the literature [15]. This can be explained by better medical control of these 2 variables and the low rate of diabetic patients who underwent KT.

Results concerning donor age and gender were concomitant with previous studies [16,17] with simultaneous increase in serum creatinine at one year especially in young recipients getting kidney grafts from old donors as well as when male recipients received grafts from female donors. The explanation is probably due to the low nephron mass in old and female donors [18,19].

Various studies made it clear that the high sensitization state in the recipients and the occurrence of DGF after KT reduce long-term graft survival [20] which is in concordance with our study except in Group I where $41.5 \%$ of patients were highly sensitized without any effect on serum creatinine level at 1 year after KT. This can be explained by the use of more aggressive induction therapy (ATG-F extended protocol) and Tacro based maintenance immunosuppression in this group of patients.

Type of immunosuppressant drugs, infections, and surgical complications predicted graft survival time. In our study, patients receiving CyA-me, MMF, and Pred showed worst outcome than those given Tacro, MMF and Pred which is in accordance to other studies [21].

In hospital infections, and those at one year post KT were also different between the 4 groups as well as surgical complications. The occurrence of these events had increased the length of hospital stay and lowered the graft function in this particular group of patients as it is clearly observed in previous studies [22,23]. Results of serum creatinine post-transplant upon discharge or at 1,3 and 6 months confirm what have been established in previous studies as an important variable for graft function at one-year [4].

To conclude, the variables that appear to affect the 1 -year serum creatinine level and consequently the graft survival are shown in Table 11. Some of them are in accordance to the literature [5] and others are not. Severity of AR, infections rate, the occurrence of DGF and the presence of surgical complications are additive factors. These factors did play a major role in explaining the high serum creatinine level in Group IV patients.

Results derived from this study may be valuable in defining strategies for optimizing patient care in our center.

Table 11. Variables Affecting 1-Year Graft Survival - Comparative Table

\begin{tabular}{|c|c|c|}
\hline & Literature & Our study \\
\hline Transplant center & Y & $?$ \\
\hline Drug regimen & Y & Y \\
\hline Donor relationship & Y & $\mathbf{N}$ \\
\hline Donor age & Y & $\mathrm{Y}$ \\
\hline Donor cause of death & Y & $?$ \\
\hline Recipient race & Y & $?$ \\
\hline Transplant year & Y & $?$ \\
\hline Recipient age & Y & $\mathbf{N}$ \\
\hline Dialysis duration & Y & $\mathbf{N}$ \\
\hline CMV status & Y & $\mathbf{N}$ \\
\hline Donor race & Y & $?$ \\
\hline Recipient gender & Y & Y \\
\hline PRA & Y & $\mathbf{N}$ \\
\hline HLA - A,B,DR & Y & $\mathbf{N}$ \\
\hline Donor gender & Y & Y \\
\hline Severity of acute rejection & $?$ & $\mathbf{Y}$ \\
\hline Infections & $?$ & $\mathbf{Y}$ \\
\hline DGF & $?$ & $\mathbf{Y}$ \\
\hline Surgical complications & $?$ & $\mathbf{Y}$ \\
\hline
\end{tabular}

Abbreviation: $\mathrm{PRA}=$ Panel reactive antibody; $\mathrm{N}=$ No; $\mathrm{Y}=\mathrm{Yes}$; $?=$ unknown.

\section{Summary}

Serum creatinine level 1 year after KT is a strong predictor of long term graft survival. In our study, we have identify some risk factors associated with graft survival at 1 year. Some of them are pre-transplant factors such as: donor age, donor and recipient gender and recipient sensitization. Others are post-transplant factors: immunosuppression regimen, acute rejection severity, In Hospital and at 1 year total rate and type of infections, duration of hospital stay, DGF, serum creatinine upon discharge and at 1, 3 and 6 months and the rate and type of surgical complications. Some of these factors are fixed, others can be optimized. In our opinion, strategies should be undertaken to optimize the patient's condition in order to improve short and long term survival. Randomized clinical trials, including larger population, should be conducted to identify the factors that further improve graft survival.
Abbreviations
KT: Kidney transplantation
ESRD: End stage renal disease
RT: Renal transplant
HLA: Human leucocyte antigens 
CMV: Cytomegalovirus

ATG-F: Anti-Thymocyte globulin - Fresenius

AR: Acute rejection

Anti-IL2-R: Anti-Interleukin 2 receptor

Pred: Prednisone

CyA-me: Cyclosporin microemulsion

SGF: Slow graft function

DGF: Delayed graft function

Tacro: Tacrolimus

MMF: Mycophenolate Mofetil

HSV: Herpes simplex virus

EBV: Epstein-Barr virus

PCR: Polymerase chain reaction

BMI: Body mass index.

\section{References}

[1] Wolfe RA, Ashby VB, Milford EL, et al. Comparison of mortality in all patients on dialysis, patients on dialysis awaiting transplantation, and recipients of a first cadaveric transplant. $N$ Engl J Med 1999; 341: 1725.

[2] Hariharan S, Johnson CP, Bresnahan BA, et al. Improved graft survival after renal transplantation in the United States, 1988 to 1996. N Engl J Med 2000; 342:605-12

[3] 2011 Annual Report of the U.S. Organ Procurement and Transplantation Network and the Scientific Registry of Transplant Recipients: Transplant Data 1987-2011. Department of Health and Human Services, Health Resources and Services Administration, Healthcare Systems Bureau, Division of Transplantation, Rockville, MD; United Network for Organ Sharing, Richmond, VA; University Renal Research and Education Association. Ann Arbor, MI. Accessed online at http://srtr.transplant.h rsa.gov/annual reports/2011/default.aspx on 15th February 2014

[4] Hariharan S, McBride MA, Cherikh WS, et al. Post-transplant renal function in the first year predicts long-term kidney transplant survival. Kidney Int 2002; 62: 31.

[5] Gjertson DW. In Cecka JM, Terasaki PI, eds. Clinical Transplants, 1998

[6] Shanfield I. New experimental methods for implantation of ureter in bladder and conduit. Transplant. Proc. 1972; 4: 637.

[7] Padiyar A, Akoum FH, Hricik DE. Management of the kidney transplant recipient. Prim Care 2008; 35:433-50.

[8] Maki DG, Weise CE, Sarafin HW. A semi-quantitative culture method for identifying intravenous-catheter-related infection. $N$ Engl J Med 1977; 296:1305-9.
[9] Solez K et al. Banff 07 classification of renal allograft pathology: updates and future directions. Am J Transplant. 2008 Apr; 8(4):753-60.

[10] Keith DS, Cantarovich M, Paraskevas S, Tchervenkov J. Recipient age and risk of chronic allograft nephropathy in primary deceased donor kidney transplant. Transpl Int. 2006;19: 649-56.

[11] Katznelson S, McClelland J, Cecka JM. Primary disease effects and associations. Clinical Transplants 1994; 403-417.

[12] Meier-Kriesche H, Kaplan B. Waiting time on dialysis as the strongest modifiable risk factor for renal transplant outcomes a paired donor kidney analysis Vol. Transplantation 2002; 74: 1377-1381.

[13] Takemoto SK, Terasaki PI, Gjertson DW, Cecka JM. Twelve years' experience with national sharing of HLA-matched cadaveric kidneys for transplantation. $N$ Engl J Med 2000; 43: 1078-1084.

[14] Meier-Kreische HU, Ojo AO, Hanson JA, et al. Increased impact of acute rejection on chronic allograft failure in recent era. Transplantation 2000; 70: 1098.

[15] Ojo AO, Leichtman AB, Punch JD et al. Impact of pre-existing donor hypertension and diabetes mellitus on cadaveric renal transplant outcomes. Am J Kidney Dis 2000; 36: 153-159.

[16] Toma H, Tanabe K, Tokumoto T, Shimizu T, Shimmura H. Timedependent risk factors influencing the long-term outcome in living renal allografts: donor age is a crucial risk factor for long-term graft survival more than 5 years after transplantation. Transplantation 2001; 72: 941.

[17] Alexander GC, Sehgal AR: Barriers to cadaveric renal transplantation among blacks, women, and the poor. JAMA 1998: 1148-1152.

[18] Kwon OJ, Kwak JY, Kang CM. The impact of gender and age matching for long-term graft survival in living donor renal transplantation. Transplant Proc. 2005 Mar; 37(2):726-8.

[19] MacKenzie HS, Azuma H, Rennke HG, Tilney NL, Brenner BM: Renal mass as a determinant of late allograft outcome:Insights from experimental studies in rats. Kidney Int52: S38-S42.

[20] Sri G. Yarlagadda, Steven G, Coca et al. Association between delayed graft function and allograft and patient survival: a systematic review and meta-analysis. Nephrol Dial Transplant 2009; 24: 1039-1047.

[21] Vincenti F, Jensik SC, Filo RS et al. A long-term comparison of tacrolimus (FK506) and cyclosporine in kidney transplantation: evidence for improved allograft survival at five years. Transplantation 2002.

[22] Jay A. Fishman. Infection in Solid-Organ Transplant Recipients. $N$ Engl J Med 2007; 357: 2601-2614.

[23] Osman Y, Shokeir A, Ali-el-Dein B, et al. Vascular complications after live donor renal transplantation: study of risk factors and effects on graft and patient survival. J Urol. 2003; 169: 859-62. 